\title{
Klinik Calıșma
}

\section{Kardiyopulmoner Baypasta Serum Elektrolit ve pH Değişimleri: Stewart Yöntemi ile Analiz}

\author{
Alper KARARMAZ*, Beliz BİLGİLI*, Seçil Ayhan ÖZCAN*, Ömer AYANOĞLU*, Zuhal AYKAÇ*
}

\section{$\ddot{0 z}$}

\begin{abstract}
Amaç: Minimal vücut dıșı dolaşım sistemi (MVDD) rezervuar içermemesi, devrelerinin heparin kaplı olması, santrifugal pompa kullanması gibi özellikleri ile konvansiyonel vücut dışı dolaşım sistemlerinden (KVDD) ayrılır. Çalısmamızda MVDD ve KVDD kullanılan elektif koroner arter cerrahisi geçiren olgularda kardiyopulmoner baypas (KPB) sırasında oluşan kan gazı değişikliklerinin fizikokimyasal yaklaşımla değerlendirilmesi amaçlandı.
\end{abstract}

Gereç ve Yöntem: KVDD ya da MVDD kullanılarak koroner arter cerrahisi uygulanan 59 olgunun verileri retrospektif olarak tarand. MVDD kurulurken devreler izotonik $\mathrm{NaCl}$ ve hidroksietil nişasta solüsyonu ile dolduruldu, kanülasyondan sonra bütün olgularda "otolog prime" yapılarak bu solüsyon devre dışına alındı. KVDD hazırlanırken standart içerik ile devreler dolduruldu. KPB öncesi, $K P B$ sirasinda ve sonrasinda alınan kan gazi verileri degerlendirildi. $\mathrm{pH}, \mathrm{pCO}$, laktat, baz farkı (BE), hemoglobin ve kuvvetli iyon farkı (SID) değerleri kaydedildi. KPB ve kros klemp süreleri de kaydedildi.

Bulgular: MVDD grubu (n=29) ile karşılaştırıldığında, KVDD grubunda (n=30) KPB strasinda ve sonrasinda hemoglobin değerleri daha düşük $(p<0.001), K P B$ strasında $S I D, B E$ ve $p H$ daha yüksek bulundu $(p<0.0001)$. KVDD grubunda SID ve pH yüksekliğinin nedeni KPB başlangzç solüsyonunun yüksek sodyum içeriğiydi. MVDD grubunda KPB sırasında SID ve pH değișmezken, KPB sonrasında klor artışına bağlı olarak SID azaldı, fakat pH etkilenmedi. KVDD grubunda laktat değerleri MVDD grubundan daha yüksekti $(p<0.01)$. KPB ve kros klemp süreleri KVDD grubunda daha uzundu $(p<0.01)$.

Tartışma ve Sonuç: Vücut dışı dolaşım için MVDD kullanuldığında konvansiyonel pompaya göre hemoglobinin ve pH'nın daha stabil seyredebileceğini gösterilmiştir. Kullandığımız yüksek SID içerikli başlangıç solüsyonun ve hemodilüsyonun KVDD grubunda metabolik alkaloza neden olduğunu fizikokimyasal analiz ile saptadık.

Anahtar kelimeler: asit baz bozukluklar, kardiyopulmoner baypas sistemleri, Stewart yöntemi, fizikokimyasal analiz

Alındığı tarih: 01.03.2016

Kabul tarihi: 22.03.2016

*Marmara Üniversitesi Tıp Fakültesi, Anesteziyoloji Anabilim Dalı Yazışma adresi: Prof. Dr. Alper Kararmaz, S.B. Marmara Üniversitesi Pendik Eğitim ve Araştırma Hastanesi, Anesteziyoloj Anabilim Dalı, Üst Kaynarca, Pendik / İstanbul

e-mail: akararmaz@hotmail.com

\section{ABSTRACT}

Serum Electrolyte and pH Alterations During Cardiopulmonary Bypass: Analysis by the Stewart Method

Introduction: "Minimal Extracorporeal Circulation System" (MECC) has differences from conventional cardiopulmonary bypass (CCPB) system such as having a centrifugal pump, heparin-coated circuit without a reservoir. This study aims to physiochemically evaluate changes in blood gas levels developed during cardiopulmonary bypass in patients undergoing elective CABG surgery with MECC or $C C B P$.

Material and Method: Fifty-nine patients who had undergone coronary artery bypass surgery were screened retrospectively. MECC circuit was primed with isotonic and hydroxyethyl starch solution.Following the cannulation, prime solution was removed from the circuit by otology priming. CCPB system was primed with $1650 \mathrm{~mL}$ standard priming solution. Arterial blood gas analyses were done before, during, after CPB. The duration of $\mathrm{CBP}$ and cross-clamping, $\mathrm{pH}, \mathrm{pCO}$, lactate, base excess $(B E)$, hemoglobin values, and strong ion difference (SID) were recorded.

Results: Hemoglobin levels were low before and after the $C B P(p<0.001), S I D, B E, p H$ values were relatively higher during the $C P B$ in the $C C P B$ group $(n=30)$ compared to the MECC group $(n=29)(p<0.0001)$. Higher sodium concentration of the priming solution in the CCPB system led to high SID and $\mathrm{pH}$ values in the CCPB group. Although SID and $\mathrm{pH}$ were stable during the CPB, SID decreased as a result of increase in Cl-levels after CPB which did not influence $p H$ in the MECC group. Lactate levels were higher in the CCPB group relative to MECC group $(p<0.01)$, while $C P B$ and cross-clamping times were longer $(p<0.01)$ in the $C C P B$ group

Discussion and Conclusion: Hemoglobin levels and pH are more stable during the extracorporeal circulation when $M E C C$ is used compared to the CCPB. The priming solution with high SID and hemodilution have been determined with physicochemical analysis as the causes of metabolic alkalosis in the CBB group

Keywords: acid base disturbances, cardiopulmonary bypass systems, Stewart approach, physicochemical analysis 


\section{GİRIŞ}

Kalp cerrahisi sırasında kullanılan kalp akciğer pompa sistemleri yapısal olarak farklılık göstermektedir. Minimal vücut dışı dolaşım sistemleri (MVDD), rezervuar içermemesi, devrelerinin heparin kaplı olması ve santrifugal pompa kullanması gibi özellikleri ile konvansiyonel vücut dışı dolaşım (KVDD) sistemlerinden ayrılır. MVDD devrelerinin de KVDD'lar gibi önceden doldurulması gerekir, fakat rezervuar içermedikleri ve hatları daha kısa olduğu için devre hacimleri daha düşüktür $(450-800 \mathrm{~mL})$, bu nedenle otolog prime daha kolaylıkla yapılabilmektedir ${ }^{[1]}$.

Kardiyopulmoner baypas (KPB) için kullanılan KVDD devreleri, merkezlerin klinik protokollerine göre değişik elektrolit içerikli başlangıç solüsyonları ile doldurulmaktadır.KPB ile gerçekleştirilen kalp cerrahisinde en sık metabolik asidoz ile karşılaşılmakta$\mathrm{d}{ }^{[2]}$. Genellikle metabolik asidozun doku perfüzyon bozukluğuna bağlı gelişen laktat yüksekliği kaynaklı olduğu düşünülmekteydi ${ }^{[3]}$. Fakat yapılan çalışmalar metabolik asidozun doku perfüzyon bozukluğundan daha çok iyatrojenik olduğunu, KPB devresi başlangıç solüsyonlarının elektrolit içeriklerine bağlı olarak da gelişebileceğini göstermektedir ${ }^{[4]}$. Karbondioksit parsiyel basıncı ve bikarbonat düzeyi ile $\mathrm{pH}$ 'yı hesaplayan Henderson-Hasselbalch formülü $(\mathrm{pH}=6.1$ $\left.+\log \left[\left(\mathrm{HCO}_{3}^{-}\right) / 0.03 \times\left(\mathrm{CO}_{2}\right)\right]\right)$ serum elektrolit düzeyi değişikliklerinin $\mathrm{pH}$ 'ya etkisini açıklamada yetersiz kalmaktadır. Elektrolitlerin pH üzerine etkileri, ancak Stewart yaklaşımı ile değerlendirilebilir. KPB sırasında gelişen asidozun "Strong ion difference" (SID)'deki azalma ile ilişkili olduğu gösterilmiştir [2] Çalışmamızda MVDD ve KVDD sistemleri kullanılan elektif koroner arter cerrahisi hastalarında pompa sırasında ve sonrasında oluşan serum elektrolit ve $\mathrm{pH}$ değişiklikleri araştırılmıştır.

\section{GEREÇ ve YÖNTEM}

Etik Kurul onamı alındıktan sonra, Ocak-Haziran 2015 tarihleri arasında, KVDD ya da MVDD kullanılarak elektif koroner arter cerrahisi uygulanan 59 hasta retrospektif olarak incelenmiştir. Kliniğimizde bu hasta grubuna standart bir anestezi indüksiyonu (midazolam $0.1 \mathrm{mg} / \mathrm{kg}$, fentanil 3-5 mcg $/ \mathrm{kg}$, propofol $0,5-1 \mathrm{mg} / \mathrm{kg}$ ve roküronyum $0.6 \mathrm{mg} / \mathrm{kg}$ ) ve idamesi (propofol $50-75 \mathrm{mcg} / \mathrm{kg} / \mathrm{dk}$. ve fentanil $1-2 \mathrm{mcg} / \mathrm{kg} / \mathrm{st}$ infüzyonu, gerektikçe roküronyum $0.3 \mathrm{mg} / \mathrm{kg}$ ) uygulanmaktadır. Preoperatif böbrek yetmezliği olanlar, pompaya girmeden önce $\mathrm{pH}<7.3$ ya da $>7,5$, standart $\mathrm{BE}<-4$ ya da $>4$ olanlar, ciddi elektrolit bozukluğu olanlar ve albümin değeri $2,5 \mathrm{~g} / \mathrm{dL}$ 'in altındaki olgular incelemeye dahil edilmemiştir.

MVDD kurulurken kliniğimizde standart olarak devreler \%6 HES 130/0.4 solüsyonu (500 mL) ve izotonik sodyum klorür $(300 \mathrm{~mL})$ ile doldurulmaktadır. Kanülasyondan sonra bütün olgularda otolog prime yapılarak pompa devreleri hasta kanıyla doldurulur ve başlangıç solüsyonu devre dışına alınır. KVDD hazırlanırken ise, Isolyte-S $1000 \mathrm{~mL}, \% 6$ HES 130/0.500 ml, \%20 mannitol $150 \mathrm{~mL}, \mathrm{NaHCO}_{3}$ $60 \mathrm{mEq}$, Heparin $10.000 \mathrm{U}$ kullanılmaktadır (toplam $1650 \mathrm{~mL}$ ). Her iki pompa tipinde membran oksijenatörü aynıdır (Quadrox-i, Maquet, Germany). Kros klemp konması gibi bazı kısa süreli istisnalar dışında pompa hızı ortalama arter basıncinı $50-80 \mathrm{mmHg}$ düzeyinde tutacak şekilde $2.2-2.41 / \mathrm{m}^{2} / \mathrm{dk}$.' dır. Olguların tümünde miyokardial koruma için aralıklı antegrad soğuk kardiyopleji uygulanır. Kliniğimizde vücut sıcaklığı MVDD kullanıldığında $34^{\circ} \mathrm{C}$, KP kullanıldığında ise $30-34^{\circ} \mathrm{C}$ olacak şekilde ayarlanmaktadır. Çalışmamızda, bu yöntemlerin kullanıldı$\breve{g}_{1}$ hastaların kalp akciğer pompasına girmeden önce, girildikten $10 \mathrm{dk}$. sonra ve KPB'nin sonlandırıldık$\tan 10 \mathrm{dk}$. sonra alınmış olan arter kan gazı verileri değerlendirildi. Sodyum, potasyum, klor, iyonize kalsiyum, laktat, $\mathrm{pH}, \mathrm{PaCO}_{2}$ ve hemoglobin değerleri kan gazı cihazı (ABL700, Radiometer, ABD) ile ölçülürken, bikarbonat ve BE değerleri aynı cihaz tarafından hesaplandi. Bikarbonat için $24 \pm 2 \mathrm{mEq} / \mathrm{L}$, $\mathrm{BE}$ için $0 \pm 2 \mathrm{mEq} / \mathrm{L}$ normal de ğerler olarak kabul edildi. pH, $\mathrm{PaCO}_{2}$ ve $\mathrm{PaO}_{2}$ değerleri alfa stat yöntemi kullanılarak analiz edildi. SID [( $\mathrm{Na}+\mathrm{K}+\mathrm{Mg}+\mathrm{Ca})-$ (Cl+laktat)] formülü ile hesaplandı ve normal değer olarak $40 \pm 3.8 \mathrm{mEq} / \mathrm{L}$ alınd ${ }^{[5]}$. Kan transfüzyonları Avrupa Göğüs Cerrahları Derneği (Society of Thoracic Surgeons) ve Kardiyovasküler Anezteziyologları Derneği (Society of Cardiovascular Anesthesiologist) 2011 kılavuzuna göre yapıldı ${ }^{[6]}$. Yapılan cerrahi işlemler, pompa ve kros klemp süreleri kaydedildi. Kullanılan başlangıç solüsyonları ve idame sıvısının elektrolit içerikleri, SID ve efektif SID $(\mathrm{SIDe}=$ Anyonlar - invivo metabolize olmayan katyonlar) değerleri Tablo 1'de verildi. 
Çalı̧̧mada istatistiksel analiz için SPSS istatistik paket programı (versiyon 21.0, SPSS Inc., Chicago, IL) kullanıldı. Verilerin dağılımının normal olup olmadı $\breve{g} 1$ " $D$ ' Agostino-Pearsonomnibus" testi ile belirlendi. Yineleyen verilerin karşılaştırılmasında dağılı$\mathrm{m}$ normal olan veriler için tek yönlü varyans analizi (ANOVA) ve farklılığa neden olan grubun tespitinde "post hoc" testi olarak "Scheffe" kullanıldı, dağılımı normal olmayan veriler ise Kruskal-Wallis testi kullanılarak analiz edildi. Gruplar arası karşılaştırmalarda bağımsız örnekler (independent samples) t ya da Man-Whitney U testleri, oransal verilerin analizinde ise $X^{2}$ testi kullanıldı. Sonuçlar \% 95 güven aralığında, $\mathrm{p}<0.05$ anlamlılık düzeyinde değerlendirildi. Veriler ortalama \pm standart sapma, ortalama $\pm \% 95$ güven aralığı ya da sayı (\%) olarak gösterildi.

\section{BULGULAR}

KVDD grubunda 30 (\%50.8), MVDD grubunda 29 (\%49.2) olgu çalışmaya dâhil edildi. Grupların yaş, cinsiyet ve vücut yüzey alanları benzerken; KVDD grubunda baypas ve kros klemp süresi, 3'lü ve 4'lü koroner arter baypas sayıları anlamlı yüksekti (Tablo 2).

Tablo 1. Konvansiyonel vücut dışı dolaşım (KVDD) ve minimal vücut dışı dolaşım (MVDD) devrelerinde kullanılan başlangıc solüsyonlarının ve idame sıvısı olarak kullanılan İsolyte S'nin elektrolit içerikleri, "strong ion difference" (SID) ve efektif "strong ion difference" (SIDe) değerleri.

$\mathrm{Na}^{+} \mathrm{Mg}^{++} \mathrm{K}^{+} \mathrm{Cl}^{-}$Asetat Glukonat $\mathrm{HCO}^{-}$SID $\mathrm{SID}^{e}$

\begin{tabular}{lccccccccc}
\hline $\mathrm{mEq} / \mathrm{L}$ & & & & & & & & & \\
$\mathrm{KVDD}$ & 178 & 1.3 & 3.2 & 112 & 17 & 15 & 39 & 0 & 70,5 \\
MVDD & 154 & & & 154 & & & & 0 & 0 \\
İsolyte $\mathrm{S}^{*}$ & 141 & 3 & 5 & 98 & 27 & 23 & & 0 & 50 \\
\hline
\end{tabular}

*ek olarak $1 \mathrm{mEq} /$ L fosfor içermektedir.

Tablo 2. Hasta özellikleri.

\begin{tabular}{lccc}
\hline & $\begin{array}{c}\text { MVDD } \\
(\mathbf{n = 2 9})\end{array}$ & $\begin{array}{c}\text { KVDD } \\
(\mathbf{n = 3 0})\end{array}$ & $\mathrm{P}$ \\
\hline Yaş (y11) & $62.3 \pm 14.4$ & $60.7 \pm 12.3$ & $\mathrm{~ns}$ \\
Cinsiyet (K/E) & $14 / 15$ & $12 / 18$ & $\mathrm{~ns}$ \\
Vücut yüzey alanı (m $\left.{ }^{2}\right)$ & $1.9 \pm 0.2$ & $1.8 \pm 0.2$ & $\mathrm{~ns}$ \\
Baypas süresi (dk.) & $64.4 \pm 20.6$ & $81.8 \pm 19.4$ & 0.002 \\
KK süresi (dk.) & $34.9 \pm 10.1$ & $46,5 \pm 14.6$ & 0.001 \\
Operasyon+ Greft sayıs1 & & & \\
$\quad$ KABG1 & 4 & 0 & $\mathrm{~ns}$ \\
$\quad$ KABG2 & 17 & 4 & 0.0004 \\
$\quad$ KABG3 & 8 & 17 & 0.04 \\
$\quad$ KABG4+ & 0 & & 0.002 \\
\hline
\end{tabular}

KK: Kros Klemp KABG: koroner arter baypas greft saylsi, KVDD: Konvansiyonel vücut dıșı dolaşım, MVDD: Minimize edilmis vücut dışı dolaşım

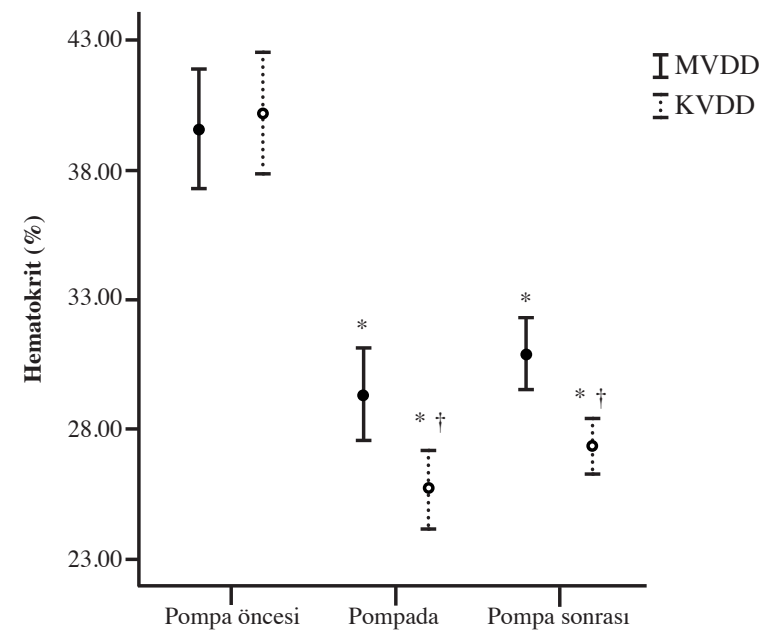

Sekil 1. Hematokrit değerlerindeki değişim (Ortalama \pm \%95 Güven aralığı).

KVDD: Konvansiyonel vücut dişı dolaşım , MVDD: Minimal vücut dışı dolaşım

* Başlangıç de ğerine göre anlamlı de ğişim $(p<0.0001)$

$\dagger$ Diğer gruptan anlamll farklıllk $(p<0.0001)$

Her iki grupta da hematokrit değerleri KPB öncesi ile karşılaştırıldığında pompada ve KPB sonrasında daha düşüktü $(p<0.0001)$. KVDD grubundaki hematokrit düşüşü MVDD grubundaki düşüşe göre anlamlı daha fazlayd 1 ( $\mathrm{p}<0.0001)$ (Şekil 1). KVDD gurubunda $21(\% 70)$ olguya, MVDD grubunda ise $10(\% 35)$ olguya intaroperatif eritrosit replasmanı uygulandı, 2 grup arasındaki farklılık istatistiksel olarak anlamlı düzeydeydi $(\mathrm{p}=0.009)$.

KVDD grubunda, KPB sirasinda ve sonrasinda $\mathrm{pH}$, BE ve SID değerleri anlamlı olarak yüksekti (Şekil 2). MVDD grubunda BE ve SID değerleri KPB sonrası dönemde başlangıç değerine göre istatistiksel anlamlı düşüktü. MVDD grubunda $\mathrm{pH}$ değerinde istatistiksel anlamlı düzeyde farklılık oluşmadı (Şekil 2). KPB öncesi ve KPB sirasinda laktat düzeylerinde 2 grupta da anlamlı farklılık yokken, KPB sonrası laktat düzeyi KVDD grubunda hem başlangıç değerine hem de MVDD grubuna göre yüksekti (Şekil 2).

KVDD grubunda KPB sırasında SID'deki artışın en belirgin nedeni $\mathrm{Na}+$ düzeyindeki artış iken, MVDD grubunda KPB sonrası SID düzeyindeki düşüşün nedeni Cl- iyonu artışıydı (Tablo 3). $\mathrm{PaCO}_{2}$ değerleri karşılaştırıldığında grup içi ve gruplar arası istatistiksel anlamlı düzeyde farklılık saptanmadı (Tablo 3). 

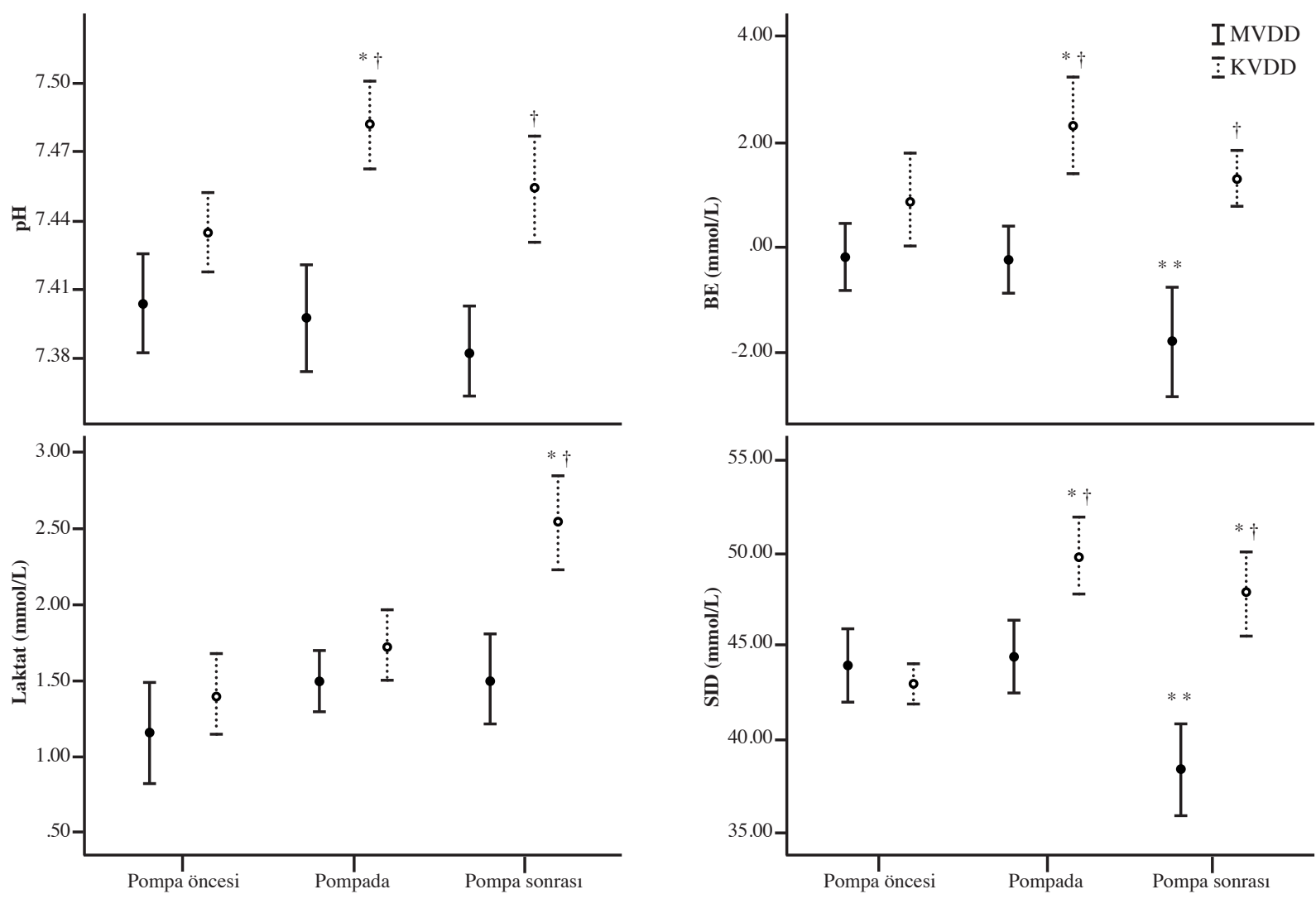

Şekil 2. Bazı kan gazı parametrelerinin kardiyopulmoner baypas sırasında ve sonrasında değişimi (Ortalama \pm 95 Güven aralı̆̆ı).

KVDD: Konvansiyonel vücut dışı dolşaım, MVDD: Minimal vücut dışı dolaşım, BE: Baz açı̆̆l, SID: Strong ion difference

* Başlangıç değerine göre anlamlı de ğişim $(p<0.0001)$

** Başlangıç değerine göre anlamlı değişim $(p<0.005)$

$\dagger$ Diğer gruptan anlaml farklılık $(p<0.0001)$

Tablo 3. Elektrolit ve parsiyel arteriyel karbondioksit basıncı (PaCO2) değişiklikleri.

\begin{tabular}{lcccccc}
\hline & \multicolumn{3}{c}{ MVDD $(\mathbf{n}=\mathbf{2 9})$} & \multicolumn{3}{c}{ KVDD $(\mathbf{n}=\mathbf{2 9})$} \\
\cline { 2 - 7 } $\mathbf{m E q} / \mathbf{L}$ & KPB öncesi & KPB & KPB Sonrası & KPB öncesi & \multirow{2}{*}{ KPB } & KPB Sonrası \\
\hline $\mathrm{Na}+$ & $141.5 \pm 3.03$ & $142 \pm 2.3$ & $142.2 \pm 3.6$ & $140.2 \pm 2.5$ & $145.2 \pm 4.8^{*}$ & $144.3 \pm 6.7^{*}$ \\
$\mathrm{Cl}-$ & $102.3 \pm 4.7$ & $103.2 \pm 5.4$ & $106.8 \pm 8.1^{*}$ & $102.4 \pm 5.3$ & $98.3 \pm 8.6$ & $101.3 \pm 4.7$ \\
$\mathrm{~K}+$ & $4.8 \pm 0.6$ & $4.9 \pm 0.5$ & $5.01 \pm 0.6$ & $4.7 \pm 0.5$ & $4.9 \pm 0.6$ & $5 \pm 0.3$ \\
$\mathrm{Ca}++$ & $4.8 \pm 0.2$ & $4.7 \pm 0.3$ & $5.1 \pm 0.3$ & $4.8 \pm 0.4$ & $5 \pm 0.4$ & $4.9 \pm 0.3$ \\
$\mathrm{PaCO}_{2}(\mathrm{mmHg})$ & $36.5 \pm 5.5$ & $34.8 \pm 4.8$ & $37.2 \pm 4.1$ & $36.8 \pm 3.5$ & $35.7 \pm 4.2$ & $36.3 \pm 3.9$ \\
\hline
\end{tabular}

KPB: Kardiyopulmoner baypas, KVDD: Konvansiyonel vücut dışı dolaşım , MVDD: Minimal vücut dışı dolaşım

* Grup içi başlangıç değerine göre ve diğer grubun eşzamanlı değerine göre anlamlı farklılık $(p<0.005)$

Tüm olgularda idame sıvısı olarak isolyte S (Eczacıbaşı Baxter, İstanbul) kullanıldı. KPB başlayıncaya kadar kullanılan Isolyte-S MVDD grubunda $(740.6 \pm 133.4 \mathrm{ml})$, KVDD grubuna $(354.5 \pm 213.8$ $\mathrm{mL})$ göre anlamlı yüksekti $(\mathrm{p}<0.0001)$.

\section{TARTIŞMA}

Bu çalışmada kardiyopulmoner baypas için MVDD tercih edildiğinde hafif hiperkloremikasidoza eğilim olsa da pH'nın daha stabil seyrettiği ve hematokritin KVDD'ye göre daha iyi korunduğu tespit edilmiştir.

KVDD sistemlerinden yapısal olarak farkları bulunan MVDD sisteminin bu yapısal farklılıkları çeşitli klinik sonuçlar doğurmaktadır. MVDD sisteminde, venöz rezervuarın bulunmaması ve heparin kaplı kısa devreler sayesinde daha az başlangıç solüsyo- 
nu kullanılmaktadır. Başlangıç solüsyonunun miktarı ile pompa sırasında görülen hemodilüsyon doğru orantılıdır. MVDD sisteminde azalmış başlangıç solüsyon miktarı sayesinde hemodilüsyonun azaldığ pompa sirasinda hemoglobin düzeylerinin KVDD'a göre daha yüksek seyrettiği gösterilmiştir ${ }^{[7-10]}$. Ayrıca MVDD sisteminde santrifügal pompa bulunmaktadır. Pompanın özelliği sayesinde eritrosit hücre hasarı KVDD'de kullanılan dönen pompaya göre daha az olmaktadır ${ }^{[1]}$. Böylece hemoliz oranı da azalmaktadır ${ }^{[11]}$. Çalışmamızda pompa sırasında her 2 sistemde de hemotokrit düzeyleri pompa öncesi döneme göre düşmekle birlikte, MVDD sisteminde düşüş daha az gerçekleşmiştir. $\mathrm{Bu}$ nedenle MVDD grubundaki olgulara daha az kan transfüzyonu uygulanmıştır. Kan transfüzyon miktarının azaltılması ile infeksiyon, uygulama hatalarına bağlı riskler ve transfüzyon komplikasyonları azaltılırken maliyetin de düşürülmesi olasıdır ${ }^{[12]}$. KVDD grubunda baypas ve kros klemp sürelerinin daha uzun olması, 3'lü ve 4'lü greft uygulanan hastaların sayısının fazla olması hemotokrit düzeyinin azalmasının diğer nedenleri olabilir.

KPB sırasında serum pH'sı, pompa başlangıç solüsyonu, kardiyopleji ve intravasküler uygulanan sıvıların elektrolit içeriklerinden etkilenebilir ${ }^{[2]}$. Çalışmamızda, intravasküler sıvı replasmanı amacıyla pH'sı 7.4 ve elektrolit içeriği serum elektrolit içeriğine yakın olan Isolyte-S (Tablo 1) kullanıldığ 1 için replasman sıvısına bağlı oluşabilecek pH değişikliklerinin minimalize edildiğini düşünüyoruz. Yapılan çalışmalar KPB sırasında pH'yı asıl etkileyen faktörün farklı elektrolit içerikli başlangıç solüsyonlarının yarattığı SID değişimi olduğunu göstermektedir ${ }^{[4,13]}$. Başlangıç sıvılarının klor gibi anyonlardan zengin olması SID azalmasına dolayısı ile metabolik asidoza neden olur. Stewart yaklaşımında $\mathrm{pH}$ değişimine neden olan 3 temel belirleyici vardır: arteriyel karbondioksit basince $\left(\mathrm{PaCO}_{2}\right)$, SID ve total zayıf asitler (plazma proteinleri, fosfat, sülfat vb.) ${ }^{[4]}$. Bu yaklaşıma göre SID azalırsa elektro-nötralite gereği su disosiyasyona zorlanır ve $\mathrm{H}+$ ve $\mathrm{OH}$ - iyonlarına ayrışır ${ }^{[4]}$. $\mathrm{H}+$ iyonunun ortamdaki artışı pH'ın azalması ve asidoz ile sonuçlanır ${ }^{[14]}$. KPB sırasında gelişen bu iatrojenik asidozun mortalite veya morbiditeye etkisi konusunda henüz yeterince klinik çalışma yoktur. Başlangıç solüsyonlarının metabolik asidoza yol açabileceğinin bilinmesinin asit baz bozukluğunun tedavisinin yönlendirilmesi açısından önemli olduğunu düşünüyoruz.
MVDD devreleri kurulurken kullanılan başlangıç solüsyonları protein içermemektedir. Yüksek miktarda Cl- iyonu (154 mEq/L) içeren bu sıvıların SID değeri sıfırdır (Tablo 1). Bu nedenle metabolik asidoza neden olmaları beklenir. Bu sıvıların asit baz dengesine etkileri için SID değerleri kadar uygulanan miktarları da önem taşır. MVDD devrelerini başlangıçta doldurabilmek için $800 \mathrm{ml}$ sıvı kullanılmışıı. Fakat olguların tümünde otolog prime yapılarak bu sıvının hepsi devre dışına alınmıştır. Sonuç olarak, pompaya ilk girildiğinde hasta serumu KPB başlangıç solüsyonu içermemiştir. Şekil 2 incelendiğinde bu grupta pompada alınan kan gazı analizinde SID, $\mathrm{pH}$ ve BE değerlerinin değişmediği görülmektedir. MVDD devreleri pompa aspiratörü içermemektedir. Bu nedenle KPB süresince kanama nedeniyle oluşan kayıpların ve hastanın kaybettiği sıvıların yerine konulabilmesi için devre dışına alınan başlangıç solüsyonu kullanılmaktadır. Düşük SID’li bu sıvının kullanılmasının etkisi de KPB sonrası yapılan kan gazı analizinde SID ve BE değerlerinde düşme olarak gözlenmiştir (Şekil 2). Aynı dönemde pH'nın çok değişmemesinin 2 nedeni olabileceğini düşünüyoruz. Birincisi $\mathrm{pH}$ logaritmik bir skala olduğu için girdilerdeki değişkenler her zaman sonucu aynı oranda değiştirmeyebilir. İkincisi hiç protein içermeyen bu sıvı nedeniyle plazma proteinlerindeki dilüsyon alkaloza eğilime neden olmuş olabilir. Protein ve fosfat içermeyen sıvıların uygulanması verilen volüme bağlı olarak total zayıf asitlerin (albümin, fosfat) azalması, SID'de artışı ve metabolik alkalozla sonuçlanır ${ }^{[4,5,15]}$.

Kardiyopulmoner baypas için KVDD sistemlerinin kullanıldığı grupta ise başlangıç solüsyonunda yüksek Na+ içeriği nedeniyle SID değeri oldukça yüksek (70,5 mEq/L) ve kullanılan volüm de diğer grubun iki katından fazlaydı (1650 mL). Dahası bu grupta hiçbir olguya otolog prime yapılmadı. Başlangıç solüsyonunun tümü KPB başladığı andan itibaren hasta serumuyla karıştı. Yüksek SID içerikli bu sıvı nedeniyle KPB sırasındaki BE ve $\mathrm{pH}$ değerlerinin yüksek olduğu görülmektedir (Şekil 2). Bu grupta pH'yı artıran bir diğer faktör yine plazma proteinlerinin dilüsyonu olabilir. Figge ve ark. ${ }^{[16]}$ hemoglobin konsantrasyonundaki düşüşün hemodilüsyonun derecesi hakkında fikir verebileceğini bildirmişlerdir. Çalışmamızda, KVDD grubunda \%40 civarında olan hematokrit değerinin KPB sırasında \%25 düzeylerine düşmesi yaklaşık \%40 oranında hemodilüsyon olduğunu 
göstermektedir. Bu grupta pompa sonrası dönemde de devam eden metabolik alkalozun bir diğer nedeni MVDD grubuna göre iki kat daha fazla kan replasmanı yapılmış olması olabilir. Bir ünite banka kanının yaklaşık $17 \mathrm{mEq} / \mathrm{L}$ trivalentsitrat içermesi nedeniyle her bir ünite kan replasmanı SID'de yaklaşık 38 $\mathrm{mEq} / \mathrm{L}$ artar. $\mathrm{Bu}$ nedenle kan replasmanının metabolik alkaloza neden olması beklenir ${ }^{[14]}$.

Shinde ve ark. ${ }^{[17]}$ KPB sırasında laktat artışının hipotermi, hemodilüsyon, düşük pompa akım miktarı ve aşırı nörohümoral aktivasyon sonucu gelişebileceğini bildirmişlerdir. Çalışmamızda KVDD grubunda laktat değerlerinin yüksekliğinin hemodilüsyon, uzamış kros klemp ve pompa süresi ile ilişkili olabileceğini düşünüyoruz. KVDD grubunda artmış laktat düzeylerine rağmen metabolik alkalozun KPB sonrası dönemde de devam etmesi dikkat çekiciydi. Bu dönemde yüksek serum $\mathrm{Na}+$ değeri nedeniyle laktatın asidotik etkisinin maskelendiğini düşünüyoruz. Yapılan çalışmalarda, metabolik alkaloz ve metabolik asidozun bir arada bulunduğu durumlarda fizikokimyasal analizin Stewart yaklaşımı ile daha kolay anlaşılabileceği gösterilmiştir ${ }^{[2,3,16,18,19]}$.

Metabolik alkalozun oksihemoglobin disosiyasyon eğrisini sağa kaydırarak, serum kalsiyum miktarını ve miyokardiyal kontraktiliteyi azaltarak doku oksijen sunumunu azaltabileceğini biliyoruz [20]. Hemoglobinin de MVDD grubunda daha iyi korunduğunu göz önüne alarak, KPB için MVDD kullanılmasının doku oksijen sunumu açısından KVDD'a üstün olabileceğini düşünüyoruz. Doku oksijen sunumu ve tüketimi ile ilgili bu iki KPB sistemini karşılaştıran çalışmalar bu konuyu aydınlatacaktır.

Çalışmamızın çeşitli kısıtlılıkları bulunmaktadır. Öncelikle tek merkezde, retrospektif yapılan ve sadece elektifkoroner arter cerrahisi uygulanan hastalar çalışmaya dâhil edilmiştir. Bu, çalışmamızın sonuçlarınındiğer cerrahi tip ve durumlar için yaygınlaştırılmasını kısıtlamaktadır. Ayrıca, KPB sırasında ve sonrasında zayıf asitlerin (albumin, fosfat) düzeylerine rutin olarak bakmadığımız için ATOT- ve kuvvetli iyon açı̆̆ 1 "strong ion gap" değişiklikleri üzerine iki KPB sistemin etkilerini direkt olarak ölçemedik ve karşılaştıramadık. KPB sırasında ortaya çıkan pH değişiminin doku oksijen sunumuna, kardiyovasküler sistem de dahil organ sistemlerine ve prognoza olan etkilerini göstermek için yeterli olgu sayısına ve monitörizasyon olanaklarına sahip değildik. İdrar elektrolit içeriklerindeki değişim ve diğer kompanzasyon mekanizmalarını monitorize edilmemiş olması da çalışmamızın bir diğer kısıtlılığıdır.

Sonuç olarak, yüksek SID içerikli başlangıç solüsyonları metabolik alkaloza neden olabilir. Bu nedenle KVDD için başlangıç solüsyonu içeriğini gözden geçirmemiz gerektiğini düşünüyoruz. Sonuçlarımız KPB için MVDD sistemi kullanıldı ̆̆ında hemoglobinin ve pH'nın daha stabil seyredebileceğini göstermektedir. MVDD ile hemoglobinin daha iyi korunduğu ve daha az kan transfüzyonu gerekliliği olduğu daha önce yapılan çalışmalarda gösterilmişti ${ }^{[1,7-11]}$. Fakat bildiğimiz kadarıyla bu çalışma MVDD'nin asit baz dengesi üzerine olumlu etkisini gösteren ilk çalışmadır.

Çıkar Çatışması: Yazarlar çıkar çatışması bildirmemektedir.

\section{KAYNAKLAR}

1. Formica F PG. Miniaturized Extracorporeal Circulation. Front Lines of Thor Surg 2012. http://dx.doi.org/10.5772/25892

2. Alston RP, Cormack L, Collinson C. Metabolic acidosis developing during cardiopulmonary bypass is related to a decrease in strong ion difference. Perfusion 2004;19(3):145-52. http://dx.doi.org/10.1191/0267659104pf751oa

3. Williams EL, Hildebrand KL, McCormick SA, Bedel MJ. The effect of intravenous lactated Ringer's solution versus $0.9 \%$ sodium chloride solution on serum osmolality in human volunteers. Anesth Analg 1999;88(5):999-1003.

4. Liskaser FJ, Bellomo R, Hayhoe M, Story D, Poustie $\mathbf{S}$, Smith B, et al. Role of pump prime in the etiology and pathogenesis of cardiopulmonary bypass-associated acidosis. Anesth 2000;93(5):1170-3. http://dx.doi.org/10.1097/00000542-200011000-00006

5. Gunnerson KJ. Clinical review: the meaning of acidbase abnormalities in the intensive care unit part I - epidemiology. Critical Care (London, England). 2005; 9(5):508-16.

http://dx.doi.org/10.1186/cc3796

6. Ferraris VA, Brown JR, Despotis GJ, Hammon JW, Reece TB, Saha SP, et al. 2011 update to the Society of Thoracic Surgeons and the Society of Cardiovascular Anesthesiologists blood conservation clinical practice guidelines. Ann Thor Surg 2011;91(3):944-82. http://dx.doi.org/10.1016/j.athoracsur.2010.11.078

7. Anastasiadis K, Antonitsis $\mathbf{P}$, Haidich $\mathbf{A B}$, Argiriadou H, Deliopoulos A, Papakonstantinou C. Use of 
minimal extracorporeal circulation improves outcome after heart surgery; a systematic review and metaanalysis of randomized controlled trials. Intern J Card 2013;164(2):158-69. http://dx.doi.org/10.1016/j.ijcard.2012.01.020

8. Yilmaz A, Sjatskig J, van Boven WJ, Waanders FG, Kelder JC, Sonker U, et al. Combined coronary artery bypass grafting and aortic valve replacement with minimal extracorporeal closed circuit circulation versus standard cardiopulmonary bypass. Interactive Card Thor Surg 2010;11(6):754-7.

http://dx.doi.org/10.1510/icvts.2010.241943

9. Panday GF, Fischer S, Bauer A, Metz D, Schubel J, El Shouki N, et al. Minimal extracorporeal circulation and off-pump compared to conventional cardiopulmonary bypass in coronary surgery. Interactive Card Thor Surg 2009;9(5):832-6. http://dx.doi.org/10.1510/icvts.2009.206466

10. Yuruk K, Bezemer R, Euser M, Milstein DM, de Geus HH, Scholten EW, et al. The effects of conventional extracorporeal circulation versus miniaturized extracorporeal circulation on microcirculation during cardiopulmonary bypass-assisted coronary artery bypass graft surgery. Interactive Card Thor Surg 2012;15(3):364-70. http://dx.doi.org/10.1093/icvts/ivs271

11. Liu Y, Tao L, Wang X, Cui H, Chen X, Ji B. Beneficial effects of using a minimal extracorporeal circulation system during coronary artery bypass grafting. Perfusion 2012;27(1):83-9.

http://dx.doi.org/10.1177/0267659111424636

12. Kalp ve Anestezi. In: Dönmez A, editor. Kalp ve Anes- tezi: Intertıp Yayınevi; 2015. p. 66.

13. Chuah $\mathbf{C}$, Kirkbride R, Alston R, Irons J. Hydrogen ion concentration and coronary artery bypass graft surgery with and without cardiopulmonary bypass. J Card Surg 2013;8:184.

http://dx.doi.org/10.1186/1749-8090-8-184

14. Wilkes P. Hypoproteinemia, strong-ion difference, and acid-base status in critically ill patients. J Appl Physiol (1985). 1998;84(5):1740-8

15. John A Kellum PWE. Stewart's Textbook of AcidBase. Second edition ed: AcidBase.org; 2013.p. 504.

16. Figge J, Mydosh T, Fencl V. Serum proteins and acid-base equilibria: a follow-up. J Lab Clinical Med 1992;120(5):713-9.

17. Shinde SB, Golam KK, Kumar P, Patil ND. Blood lactate levels during cardiopulmonary bypass for valvular heart surgery. Ann Card Anaesth 2005;8(1):39-44.

18. Fencl V, Leith DE. Stewart's quantitative acid-base chemistry: applications in biology and medicine. Respiration Physiology 1993;91(1):1-16. http://dx.doi.org/10.1016/0034-5687(93)90085-O

19. Ranucci M, De Toffol B, Isgro G, Romitti F, Conti D, Vicentini M. Hyperlactatemia during cardiopulmonary bypass: determinants and impact on postoperative outcome. Critical Care (London, England) 2006;10(6):R167. http://dx.doi.org/10.1186/cc5113

20. Brimioulle S, Kahn RJ. Effects of metabolic alkalosis on pulmonary gas exchange. The American review of respiratory disease 1990;141(5 Pt 1):1185-9. http://dx.doi.org/10.1164/ajrccm/141.5_Pt_1.1185 